\title{
Enactment and Enforcing Processes of the Japanese Feed in Tariff Law: Difficulties for Maximizing Renewable's Diffusion while Minimizing National Burden
}

Kenji Asano*

This paper discusses enactment and enforcing processes of the Japanese renewables Feed in Tariff (FIT) Law and its amendment of 2017. Thanks to the introduction FIT in 2012, the installed capacity of renewable energy is growing rapidly. As of 2015, the renewable electricity ratio in the generated electric power amount of Japan is 14.6 percent. Meanwhile, the levy burden (surcharge) reached JPY 2.1 trillion (aprx. USD18.7 billion). Through the enactment process of the FIT Law, the upper limit of the burden initially determined by the Japanese Diet was removed. A fundamental measure could not be taken to control the installation and the burden since the law does not allow for revisions on the system based on the results of renewable installation, even if the financial burden increases rapidly. Therefore, the Japanese Diet weakened the efficiency of the FIT Law in Japan.

\section{Keywords}

Feed in Tariff, FIT Law, Renewable Energy, Japanese Diet, Article 8 Committee

\footnotetext{
* Senior Research Scientist of the Central Research Institute of Electric Power Industry (CRIEPI); Lecturer at the Institute of Innovation Research of Hitotsubashi University. Ph.D. (Kyoto). ORCID: http://orcid.org/0000-0002-67732981. The author may be contacted at: k-asano@criepi.denken.or.jp/Address: 1-6-1, Ohtemachi, Chiyoda, Tokyo, 1008126, JAPAN. 


\section{Introduction}

This paper will discuss the Act on Special Measures concerning Procurement of Electricity from Renewable Energy Sources by Electricity Utilities $^{1}$ (hereinafter Feed in Tariff Law: FIT Law) enacted in July 2012 and amended in April 2017 in Japan, respectively. The author will talk about the results and challenges for the past five years after the implementation of the FIT and further amendments. This study will focus on the legal provisions incorporated into the law to strike a balance between the "introduction and financial burden" in the operation of FIT and its operating system (in contrast, how the operation was not efficient due to lack of legal provisions).

Up to now, the relevant studies have examined the calculation process of the FIT purchase price ${ }^{2}$ and the relationship between the Japanese solar photovoltaics ("PV") policy $^{3}$ and the industrial development. ${ }^{4}$ However, few studies have analyzed "the introduction and the financial burden" of FIT regulations and the system operation.

Renewables' installation generally expands as the FIT purchase price rises; if the price is low then installed capacity shrinks. In Germany, e.g., FIT has faced mounting criticism due to its increased cost burden, most notably with regard to the adoption of PV. ${ }^{5}$ Accordingly, Japan should consider the cost burden rather than simply prioritizing the installed capacity. Under the Japanese FIT Law, the burden of the levy would not be excessive to electricity users. ${ }^{6}$ Therefore, a critical point at issue from the standpoint of policies' efficiency is to supply more power at lower cost since the additional costs of FIT are ultimately added to electricity fee as surcharge.

1 Act No. 108 of 2011. See An English translation of the Japanese law, available at http://www.japaneselawtranslation.

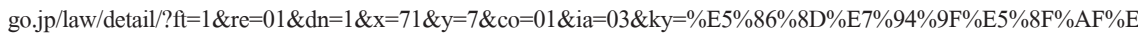
$8 \% 83 \% \mathrm{BD} \% \mathrm{E} 3 \% 82 \% \mathrm{~A} 8 \% \mathrm{E} 3 \% 83 \% 8 \mathrm{D} \% \mathrm{E} 3 \% 83 \% \mathrm{AB} \% \mathrm{E} 3 \% 82 \% \mathrm{AE} \% \mathrm{E} 3 \% 83 \% \mathrm{BC} \&$ page $=1$ (last visited on Oct. 1, 2017).

2 Yugo Tanaka et.al, International Comparison of Renewable Energy Policy Processes: An analysis of the Japanese Feed in Tariff [再生可能エネルギ一政策プロセスの国際比較: わが国の固定価格買取制度の分析], Proceeding of the Japan Society of Energy Resources’33rd National Conference (2017).

3 Osamu Kimura \& Tatsujiro Suzuki, 30 Years of Solar Energy Development in Japan, Paper prepared for the 2006 Berlin Conference on the Human Dimensions of Global Environmental Change: "Resource Policies: Effectiveness, Efficiency, and Equity (2006)," available at http://userpage.fu-berlin.de/ffu/akumwelt/bc2006/papers/Kimura_Suzuki. pdf (last visited on Oct. 1, 2017).

4 Kenji Asano, Early Promoter of Solar Photovoltaics: Forty Years Development of Policy and Technology in Japan, in Common Challenges, National Responses: The Political Economy of Renewable Energy and Energy Security in Japan, China and Northern Europe 157-74 (E. Moe \& P. Midford eds., 2014)

5 M. Frondel, N. Ritter, C. Schmidt \& C. Vance, Economic Impacts from the Promotion of Renewable Energy Technologies, EnERgy PoL'y 38, 40 \& 48-56 (2010)

6 FIT Law art. 3(4) 
This paper is composed of five parts including a short Introduction and Conclusion. Part two will review the decisions of the Japanese Diet toward the establishment of the FIT Law. Part three will discuss the calculation of the purchase price by the Calculation Committee for Procurement Prices toward actual operation. Part four will investigate the details of the 2017 amendment of the FIT Law and remaining challenges.

\section{A. Discussions by the Japanese Diet towards the establishment of the FIT Law}

\section{Establishment of the FIT Law}

The government decision on the draft FIT Law was made by the Naoto Kan Administration of the Democratic Party of Japan on March 11, 2011 (Table 1). Subsequently, while the support for the Kan Administration fell due to the inefficient response to the nuclear power plant accident, Prime Minister Kan declared that he would resign if the FIT Law were enacted. His remarks made this law highly political. On August 11 of the same year, three political parties-Democratic Party of Japan, Liberal Democratic Party, and New Komeito-reached a consensus by accepting the majority of the draft revised by the Liberal Democratic Party to establish the FIT Law.

\section{Revisions after the Deliberation of the Japanese Diet}

The final contents of the FIT Law were quite different from the initial draft examined by the Agency for Natural Resources and Energy before the Great East Japan Earthquake. ${ }^{7}$ The following subsections will highlight the four points that are different in the enacted FIT Law $^{8}$ and the draft. ${ }^{9}$

\section{a. Purchase Price, Target Power Supply, and Purchase Period}

In the draft bill, the purchase price was JPY $15-20$ per $1 \mathrm{~kW}$ and the purchase period was 15-20 years. ${ }^{10}$ If considering PV and other renewable energy power sources, there was no difference in the purchase price among any power sources other than PV.

7 The report of the project team on the total purchase amount of renewable energy and the draft was based on that; it was approved by the cabinet on March 11, 2011.

8 The FIT Law was enacted on August 26, 2011.

9 The FIT bill was approved by the cabinet on March 11, 2011.

10 Bill No. 51 (submitted by Cabinet) at 177th Diet (2011). 
Table 1: Enactment Process of the FIT Bill in Japan ${ }^{11}$

\begin{tabular}{|c|c|}
\hline Date & Processes \\
\hline March 11, 2011 & $\begin{array}{l}\text { Naoto Kan's cabinet decided to submit the bill to the Act on Special } \\
\text { Measures concerning the Procurement of Renewable Electric Energy } \\
\text { in the morning of March } 11 \text { when Great East Japan earthquake } \\
\text { occurred. }\end{array}$ \\
\hline June 15, 2011 & $\begin{array}{l}\text { Naoto Kan, the then PM, confessed in the supporter's meeting for } \\
\text { enacting FIT bill: "Some politicians said they don't even want to } \\
\text { see my face. Carry a fit bill through Parliament rapidly, if you don't } \\
\text { want to see my face anymore," including Masayoshi Son, CEO of } \\
\text { Yahoo! Japan. The story became the topic of conversation. }\end{array}$ \\
\hline Jun 27, 2011 & $\begin{array}{l}\text { Naoto Kan, the then PM, announced that he would be resigning as } \\
\text { prime minister on condition that the FIT bill and two other bill were } \\
\text { enacted. The FIT bill became some possibility of breaking a political } \\
\text { deadlock. }\end{array}$ \\
\hline July 13, 2011 & $\begin{array}{l}\text { Naoto Kan, the then PM, declared abandoning nuclear power } \\
\text { generation in the future. }\end{array}$ \\
\hline August 11, 2011 & $\begin{array}{l}\text { Naoto Kan, the then PM and Democratic Party of Japan complied } \\
\text { with the amendment bill by Liberal Democratic Party ("LDP"). The } \\
\text { three parties such as DP, LDP, and the New Komeito party reached } \\
\text { the consensus together. }\end{array}$ \\
\hline August 26, 2011 & FIT bill was enacted; PM Kan and his cabinet resigned. \\
\hline
\end{tabular}

Figure 1 summarizes the Japanese FIT Law ${ }^{13}$ from the viewpoint of "the introduction and financial burden.”

11 Compiled by the author.

12 Masayoshi Son \& A. DeWit, Creating a Solar Belt in East Japan, AsIA-PACIFIC J., Sept. 19 2011, available at http://www. japanfocus.org/-Andrew-DeWit/3603\#sthash.EiCav2yb.dpuf (last visited on Oct. 1, 2017).

13 The FIT Law enacted on August 26, 2011; implemented on July 1, 2012. 
Figure 1: Summary of the Japanese FIT Law ${ }^{14}$

Summary of Japanese FIT Law (enacted on August 26, 2011, implemented on July 1, 2012) focusing on the introduction and financial burden.

\section{- Objectives}

The objectives of the FIT Law are (1) to promote the use of renewable energy and (2) to contribute to a stronger international position, promotion of industry, rejuvenate local areas, and healthy development of national economy (Article 1).

\section{- Setting purchase obligations, price, and period of the FIT Law}

Electric utilities should be bound by the connections and contracts necessary for purchase unless there is a reason stipulated by law or the Ordinance of the Ministry of Economy, Trade, and Industry (Article 4). Electric utilities include the general electric utility, specified electric utility, and the power producer and supplier.

Purchase price and purchase period are determined by the Ministry of Economy, Trade, and Industry each year before the beginning of the next fiscal year based on the opinion of "the Calculation Committee for Procurement Prices" established as a neutral organization, discussions held with the relevant ministers (the Minister of Agriculture, Forestry and Fisheries, the Minister of Land, Infrastructure and Transport, and the Minister of the Environment), and the opinion of the Minister of State for Consumer Affairs and Food Safety (Article 3 (5)).

Setting the purchase price is based on the cost deemed necessary when the supply is implemented efficiently and determined while making a profit for those providing renewable electricity (Article 3 (2)) and considering "the amount of renewable electricity supply in Japan ... and other situations (Article 3 (2))."

Purchase period is determined by considering "the standard period from the beginning of the electricity supply to the renewal of important parts of power generation facilities" (Article 3 (3)). In addition, when setting the purchase price, special consideration is given to the companies to profit for three years following the implementation (Supplementary Provision Article 7). On the other hand, the burden of the levy would not be excessive to electricity users (Article 3(4)). The frequency of the purchase price revision is once a year, but it can be reviewed every six months if the Ministry of Economy, Trade, and Industry deems it necessary (Article 3(1)).

\section{- Reviewing process of FIT}

If a change must be made to the framework of the FIT Law, the legislature must amend the law. Specifically, the following two points are stipulated. First, whenever the basic energy plan is changed or at least every three years, the Law is reviewed as needed considering the economic situation. (Supplementary Provision Article 10(1) and (2)). Second, the implementation of the Law will be examined until the end of 2020 and a fundamental review will be performed (Supplementary Provision 10(3)). 
However, in the proposal, the price was set with an appropriate profit for the installation cost of each type of renewable energy other than PV. ${ }^{15}$ In the three years after the implementation of the law, the usage has increased. "When setting the purchase price, a special consideration is given to specific suppliers to make a profit." 16 Also, a high purchase price was stipulated.

\section{b. Purchase Price Calculation Institutions}

Purchase price is basically determined by the Ministry of Economy, Trade, and Industry. However, consultations with relevant authorities such as the Ministry of Agriculture, Forestry and Fisheries, the Ministry of Land, Infrastructure and Transport, and the Ministry of the Environment led to a decision that the opinion of the Minister of State for Consumer Affairs and Food Safety and a newly established the "Procurement Price Committee" as a neutral organization should be heard before making a decision. ${ }^{17}$

The Calculation Committee for Procurement Prices is called the "Article 8 Committee" because it was established based on Article 8 of the National Governmental Organization Act. ${ }^{18}$ Its legal status is thus different from usual government councils. Article 8 requires that: "An institution of a council system can be placed within national governmental institutions." However, the Calculation Committee for Procurement Prices appoints five members for a three-year term following the consensus of both houses of the Parliament for the appointments. It is different from typical Japanese government councils which do not require such an approval process by the Japanese diet. Compared to these councils, the involvement of the Japanese Diet in the Committee is reportedly clear and the selection of the personnel is democratic. In fact, among the members of the Calculation Committee for Procurement Prices proposed by the government in November of 2011, those from the economic organizations were replaced with academic experts during the process of the Japanese Diet approval.

Compared to the "Article 3 Committee" of National Government Organization

15 It is written in Supplementary Provision Article 7 of the FIT Law. The Procurement Price Calculation Committee took the responsibility for setting the purchase price for each type of renewable energy.

16 FIT Law Supplementary Provision, art. 7.

17 FIT Law art. 3 (5). It reads: "When the Minister of Economy, Trade and Industry intends to determine a Procurement Price, etc., the minister [...] must hear the opinions of the Calculation Committee for Procurement Prices, etc. In this case, the Minister of Economy, Trade and Industry shall respect the opinions of the Calculation Committee for Procurement Prices, etc."

18 Act No. 120 of 1948 (Amendment); Act No. 118 of 2006. See English translation of the Japanese law, available at http://www.japaneselawtranslation.go.jp/law/detail/?id=13\&vm=\&re=01 (last visited on Oct. 1, 2017). 
Act, the "Article 8 Committee" is less independent in terms of budget and staffing. In contrast, the Article 8 Committee is an institution maintaining an advisory/ investigative council system. In other words, the Calculation Committee for Procurement Prices would consult with the Minister of Economy, Trade, and Industry about purchase price, but the ultimate decision is made by the Minister of Economy, Trade, and Industry. ${ }^{19}$

The purchase price, which is a point of contention in the FIT Law, is calculated through an extremely democratic process compared to councils that are often criticized for the undisclosed personnel selection process. ${ }^{20}$ The Calculation Committee for Procurement Prices, of which the appointments are approved by the Japanese Diet, consults on the purchase price with the Minister of Economy, Trade, and Industry. Then, the Minister determines the purchase price through discussion with other relevant ministers. All the ministers are members of the Japanese Diet appointed by the Prime Minister, the leader of the ruling party. It is unusual that the Minister of Economy, Trade, and Industry is responsible for the decision on the purchase price in Japan. However, the democratic process of formal collateralization of FIT does not necessarily guarantee reasonable decision-making.

\section{c. Introduction of a Financial-burden Mitigation Measure}

In the draft, a financial-burden mitigation measure was not introduced and an equal burden by the citizens was assumed. However, in the FIT Law, if power consumption per sale in the manufacturing industry is eight times or more than the mean value for that industry, 80 percent or more of the levy on the electricity fee would be exempt. The funding for this exemption was part of the government budget for energy. It is different from the German FIT, in which the deficit is covered by the consumers who are not the subjects of exemption, especially, the end consumers in the household sector. ${ }^{21}$ In the amended FIT Law of April 2017, the funding for exemption was changed from the tax revenue of energy related special account to rate payers,

19 FIT Law art. 8. It reads: "An Administrative Organ of the State as set forth in Article 3 may, within the scope of the affairs under jurisdiction as prescribed by an Act, establish an organ having a council system for taking charge of the study and deliberation of important matters, administrative appeals or other affairs that are considered appropriate to be processed through consultation among persons with the relevant knowledge and experience, pursuant to the provisions of an Act or a Cabinet Order."

20 F. Schwartz, Advice and Consent: The Politics of Consultation in Japan 48-90 (1998). See also Hideaki Shiroyama, Administrative Reorganization and Public Sector Reform in Japan, in The Public Sector IN Transition: East Asia And The European Union Compared 233-45 (2007).

21 The German Federal Ministry for Economic Affairs and Energy, Act on the Development of Renewable Energy Sources (Renewable Energy Sources Act-RES Act 2014), available at http:/www.bmwi.de/Redaktion/EN/Downloads/ renewable-energy-sources-act-eeg-2014.pdf?_blob=publicationFile\&v=1 (last visited on Oct. 1, 2017). 
ordinarily electricity consumers who are not the subject of exemption.

\section{d. Elimination of the upper limit to the financial burden}

As for the upper limit of the financial burden, initially, the Ministry of Economy, Trade, and Industry declared that the levy unit price "did not exceed 0.5 yen per 1 $\mathrm{kWh}$ (150 yen/month for a typical household)." ${ }^{22}$

However, on August 23, the revised draft was passed by the House of Representatives. "Although the government bill stated that the financial burden would be within $0.5 \mathrm{yen} / \mathrm{kWh}$, a correction by the House of Representatives must be considered" and "the financial burden that was set at JPY 150 per month may be increased upon correction by the House of Representatives." ${ }^{23}$ In other words, political loopholes on this upper limit were secured. The levy unit price in 2014 was "0.75 yen/kWh" and continued to climb afterward. In 2017, it was "2.64 yen/kWh," well over the upper limit discussed in 2011.

\section{Summary: Enacting Process of the FIT Law by the Japanese Diet}

The FIT Law established through the corrections in the review by the Japanese Diet can be summarized in the following two points from the "introduction and financial burden" perspective.

First, the calculation of the purchase price was performed by adding an "appropriate profit' to "the usual cost of efficient supply." In contrast, it does not guarantee the cost of inefficient supply or excessive profit. However, the Calculation Committee for Procurement Prices takes responsibility for the decision on the efficiency and appropriate profit. Especially, adding a correction "to determine the procurement price, special considerations are given to specific suppliers to profit ${ }^{24}$ - in three years after the implementation of the law, purchase price increased.

Second, although consideration given to the maximum limits of consumers' financial burden in the draft bill, financial burden could no longer be controlled because the specific standard in the draft was removed. The FIT Law stipulates that the burden of the levy is not excessive to the users of electricity ${ }^{25}$ and the purchase price "is determined by considering the condition of renewable electricity supply in

22 See Q \& A session on the 177th plenary session of the House of Representatives on July 14, 2011, available at http:// kokkai.ndl.go.jp/SENTAKU/syugiin/177/0001/17707140001032a.html (last visited on Oct. 1, 2017).

23 See Q \& A session on the summary of bill by the Minister on August 24, 2011, available at http://kokkai.ndl.go.jp/ SENTAKU/sangiin/177/0001/17708240001035a.html (last visited on Oct. 1, 2017).

24 FIT Law Supplementary Provision, art. 7.

25 FIT Law art. 3(4). 
Japan ... other situations." 26

The upper limit of the financial burden initially determined by the Japanese Diet (levy unit price of $0.5 \mathrm{yen} / \mathrm{kWh}$ ) was removed. Since the law does not allow for revisions on the system based on the results of the introduction, even if the financial burden rapidly increases, a fundamental measure could not be taken. Therefore, the Japanese Diet weakened the efficiency of the FIT Law.

\section{Calculation of Purchase Price by the Calculation Committee for Procurement Prices: From the Enactment to Implementation of the FIT Law}

\section{A. Overview}

As discussed above, the purchase price and purchase period are calculated by the Calculation Committee for Procurement Prices and reported to the Ministry of Economy, Trade, and Industry. The first committee has met seven times since March 6, 2012; the related ministerial ordinance was announced on June 18 and the purchase price was established.

The most notable point of contention of the FIT Law is the purchase price. As discussed in Part two, the Japanese FIT Law requires the Calculation Committee for Procurement Prices to calculate the purchase price that has an 'appropriate profit' in addition to the "cost required for efficient supply." 27 Moreover, special consideration is given to make profits for three years following the implementation of the FIT Law. ${ }^{28}$ This part will examine how the Calculation Committee for Procurement Prices aims to operate, with the calculation of the purchase price under the FIT Law.

\section{B. Setting the Purchase Price through IRR}

The Calculation Committee for Procurement Prices uses the Internal Rate of Return ("IRR") to evaluate the profitability of projects as an index of the purchase price. As IRR before tax in Germany, where FIT was implemented earlier, is 7 percent $(8.5 \%$ $10 \%$ in Spain), Japan used 5-6 percent considering the interest rate differential. Based

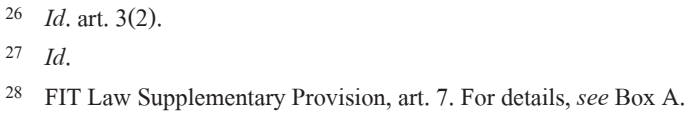


on Article 7 of the FIT Law Supplementary Provision, 7-8 percent was used for three years after the implementation. ${ }^{29}$

It is unclear if IRR is a generally accepted method to set the purchase price. In Germany, there is no indication that IRR is used as an index of purchase price calculation in discussions on the FIT Law and pricing. However, IRR has an advantage of presenting the unit purchase price without considering the impact of financing. IRR is an interest rate (discount rate) in which the initial investment and the present value of future cash flow of a project become the same, i.e., the investment yield. As new profit (cash flow) from the power generation business increases, IRR would increase (investment yield increases). It becomes a standard to determine whether to invest in a power generation business or not, based on the results of future (expected) cash flow.

IRR in the FIT Law recovers the capital investment, interest on borrowing, and corporate tax in the investment yield. Therefore, IRR is a first-step decision index that takes the risk premium into consideration. If funds can be raised at a cost lower than IRR (interest rate), businesses can be established. In other words, because the comparison of rates between IRR, interest rate, and yield from other investments is easy, IRR can be used to make a decision on investment. Since it is only the first step, the calculation of actual income and expenditure needs to be separate based on the depreciation cost and actual fundraising.

\section{Calculation of the Purchase Price by the Calculation Committee for Procurement Prices}

A total of 16 types of renewable electricity generation are targeted for purchase under FIT. Purchase prices and the periods of these power supplies from the fiscal year of 2012 to 2019 are shown in Table 2. Purchases based on the scale are PV, wind power, and hydropower, while the purchase based on the type is biomass power generation. Between 2012 and 2017 when the law was being implemented, the report by the Calculation Committee for Procurement Prices to the Ministry of Economy, Trade, and Industry was used as the purchase price as it had been. Thus, the examination by the Calculation Committee had a substantial impact on the rise of the purchase price.

29 See Handout No. 6 on the 2nd Calculation Committee for Procurement Prices (Mar. 15, 2012), Points of Attention in Hearing from Renewable Generators [資料 6. 事業者からヒアリングを行うに際しての留意点], available at http:// www. meti.go.jp/committee/chotatsu_kakaku/002_haifu.html (last visited on Oct. 1, 2017). 
Table 2: The FIT Price Level (2012-19) $)^{30}$

\begin{tabular}{|c|c|c|c|c|c|c|c|c|c|}
\hline & $\begin{array}{c}\text { FY } \\
2012\end{array}$ & $\begin{array}{l}\text { FY } \\
2013\end{array}$ & $\begin{array}{c}\text { FY } \\
2014\end{array}$ & $\begin{array}{c}\text { FY } \\
2015\end{array}$ & $\begin{array}{c}\text { FY } \\
2016\end{array}$ & \multicolumn{2}{|c|}{$\begin{array}{l}\text { FY } \\
2017\end{array}$} & $\begin{array}{c}\text { FY } \\
2018\end{array}$ & $\begin{array}{c}\text { FY } \\
2019\end{array}$ \\
\hline \multirow{2}{*}{$\begin{array}{c}\text { PV } \\
(\geqq 10 \mathrm{~kW})\end{array}$} & \multirow{2}{*}{40} & \multirow{2}{*}{36} & \multirow{2}{*}{32} & 29 & \multirow{2}{*}{24} & \multirow{2}{*}{\multicolumn{2}{|c|}{21}} & & \\
\hline & & & & 27 & & & & & \\
\hline \multirow{2}{*}{$\begin{array}{c}\mathrm{PV} \\
(<10 \mathrm{~kW})\end{array}$} & \multirow{2}{*}{42} & \multirow{2}{*}{38} & \multirow{2}{*}{37} & 33 & 31 & \multicolumn{2}{|c|}{28} & 26 & 24 \\
\hline & & & & 35 & 33 & \multicolumn{2}{|c|}{30} & 28 & 26 \\
\hline \multirow{3}{*}{ Wind } & \multicolumn{5}{|c|}{$22(\geqq 20 \mathrm{~kW})$} & 22 & 21 & 20 & 19 \\
\hline & \multicolumn{7}{|c|}{$55(<20 \mathrm{~kW})$} & & \\
\hline & & & & \multicolumn{6}{|c|}{36 (offshore) } \\
\hline \multirow{2}{*}{ Geothermal } & \multicolumn{9}{|c|}{$26(\geqq 15000 \mathrm{~kW})$} \\
\hline & \multicolumn{9}{|c|}{$40(<15000 \mathrm{~kW})$} \\
\hline \multirow{4}{*}{$\begin{array}{l}\text { Small/ } \\
\text { medium scale } \\
\text { hydraulic } \\
\text { power }\end{array}$} & \multirow{2}{*}{\multicolumn{5}{|c|}{$24(\geqq 1000 \mathrm{~kW},<30000 \mathrm{~kW})$}} & 24 & \multicolumn{3}{|c|}{$20(\geqq 5000 \mathrm{~kW},<3000 \mathrm{~kW})$} \\
\hline & & & & & & \multicolumn{4}{|c|}{$27(\geqq 1000 \mathrm{~kW},<5000 \mathrm{~kW})$} \\
\hline & \multicolumn{9}{|c|}{$29(\geqq 200 \mathrm{~kW},<1000 \mathrm{~kW})$} \\
\hline & \multicolumn{9}{|c|}{$34(<200 \mathrm{~kW})$} \\
\hline \multirow{7}{*}{ Biomass } & \multicolumn{9}{|c|}{39 (Biogas) } \\
\hline & \multirow{2}{*}{\multicolumn{3}{|c|}{$\begin{array}{l}32 \text { (Timber from } \\
\text { forest thinning) }\end{array}$}} & \multicolumn{6}{|c|}{$40(<2000 \mathrm{~kW})$} \\
\hline & & & & & & \multicolumn{4}{|c|}{$32(\geqq 2000 \mathrm{~kW})$} \\
\hline & \multirow{2}{*}{\multicolumn{5}{|c|}{24 (Other woody materials) }} & 24 & \multicolumn{3}{|c|}{$21(\geqq 20000 \mathrm{~kW})$} \\
\hline & & & & & & \multicolumn{4}{|c|}{$24(<20000 \mathrm{~kW})$} \\
\hline & & & & $13(\operatorname{Re}$ & ycled & vood & & & \\
\hline & & & $17(\mathrm{~V}$ & es exc & ading & vood & ly w & tes) & \\
\hline
\end{tabular}

Unit: JPY/kWh; 1JPY=USD 0.9 as of October 2017

The Committee gathered the cost data and performed hearings with business groups on the price decision for the fiscal year of 2012. ${ }^{31}$ Ten of the 16 purchase prices reflected the desired price by the business groups. Among those, the Committee revised downward the six construction prices from the price submitted by the business groups, but the purchase price remained the same as the price submitted by the businesses. ${ }^{32}$ It was, however, not clarified why this happened.

30 Complied by the author.

31 The Calculation Committee for Procurement Prices, The opinions of the Procurement Prices and Periods for FY2012 [平成24年度調達価格及び調達期間に関する意見], available at http://www.meti.go.jp/committee/chotatsu_ kakaku/report_001.html (last visited on Oct. 1,2017).

32 Kenji Asano, Total and additional costs estimation for renewable electricity support policies in Japan [日本における 再生可能エネルギ一普及制度による追加費用及び買取総額の推計] CRIEPI Report Y12034 (2013), Appendix 
The fundamental question on the Committee's purchase price calculation is the lack of transparency in pricing. Asano carefully examined the purchase price of biomass power generation by unused chips with various calculations relatively well publicized. He said the business groups determined the purchase price-JPY 32/kWh-lowered by JPY $10 .^{33}$ Specifically, when the price was reconsidered based on the documents submitted by the business groups to the Calculation Committee for Procurement Prices, it was estimated JPY 30/kWh. ${ }^{34}$ This was because business groups made a mistake with the timing of the decommissioning cost and the Calculation Committee for Procurement Prices did not suggest any corrections. The purchase price could be reduced to JPY $21 / \mathrm{kWh}$ if capital investment subsidies are deducted and the disclosed price of unused chips is corrected. ${ }^{35}$ However, these points were not addressed by the Committee.

\section{Application Period of Purchase Price}

According to the Japanese FIT Law, the purchase price is determined "at the time of the facility certification," 36 which is earlier than the "operation start[ing] date" that other countries apply. There are two reasons for this determination.

First, when the Calculation Committee for Procurement Prices was gathering public comments before implementing FIT, the price application period was the time of the contract. ${ }^{37}$ However, it was moved up to the facility certification date to value the investment environment in response to the requests by business groups. Such a response to public comments was to "expect the pricing as early as possible to organize the finances." 38

1, available at http://criepi.denken.or.jp/jp/kenkikaku/report/detail/Y12034.html (last visited on Oct. 1, 2017).

33 Kenji Asano, A critical consideration for Feed in tariff pricing of woody bioenergy in Japan [FIT制度おける木 質バイオマス発電の買取価格に関する考察], in ENERGY UtILIZATION FROM BIOMASS AND WASTE [バイオマ

ス・廃棄物発電によるエネルギー利用の最前線と課題] 88-98 (Yoshiba ed., 2013).

34 Id. at $95-7$.

35 Id.

36 Public Notice of the Ministry of Economy, Trade and Industry No.139 of 2012. [電気事業者による再生可能エネル ギ一電気の調達に関する特別措置法第三条第一項及び同法附則第六条で読み替えて適用される同法第四条 第一項の規定に基づき、同法第三条第一項の調達価格等並びに調達価格及び調達期間の例に準じて経済産 業大臣が定める価格及び期間を定める件]. < available only in Japanese>

37 The Agency of Natural Resources and Energy, Applications for public comments on the proposal to the Procurement Prices and Periods of the FIT Law [調達価格及び調達期間等、電気事業者による再生可能エネルギ一電気の調 達に関する特別措置法の施行関係事項に関するパブリックコメントの実施(2012)], at 42-3, available at http:// search.e-gov.go.jp/servlet/PcmFileDownload?seqNo=0000089045 (last visited on Oct. 1, 2017).

38 See The Agency of Natural Resources and Energy's response to public comments on the proposal to the Procurement Prices and Periods of the FIT Law [再生可能エネルギーの固定価格買取制度パブリックコメントに関する意 見概要及び回答 28 (2012), available at http://search.e-gov.go.jp/servlet/PcmFileDownload?seqNo=0000089049 (last 
Second, the Agency for Natural Resources and Energy was aware that changing the price application date to the certification time would bring a problem of getting facility certification without any feasibility before starting the FIT system. According to the minutes of the Calculation Committee for Procurement Prices' meeting on March 15, 2012, the Committee's member, Kenji Yamaji, maintained that the application period would be the point of contention. He identified the problem as: "Applications for facility certification are made without any feasibility assessment to receive the framing or pricing from the initial year." 39 Thus, it was stipulated that the opinions of both the Calculation Committee for Procurement Prices and the public should be heard. ${ }^{40}$ At the stage of gathering public comments, in order "to secure an advantageous procurement price despite the lack of a business plan, fraudulent cases that attempt to fix the procurement price during the design of the business plan could appear." 41 Therefore, "unless the cost of the business has been determined to a certain degree, procurement price cannot be determined" and "the procurement price from the year when the specific contract with electric utility was signed should be applied." ${ }^{42}$

Despite the knowledge about the problem of getting facility certification without any feasibility before the introduction, the Agency for Natural Resources and Energy finally prioritized renewable energy businesses by deliberately setting the purchase price to the application period. The biggest problem was that the application period was not discussed at all in councils. The Agency for Natural Resources and Energy would present its own ideas based on the differences in the application period from public comments (even if it was wrong at the end, the basis for the decision could be traced). If the problem was acknowledged from the beginning, the transparency of decision-making would have been secured through discussions with the Calculation Committee for Procurement Prices. ${ }^{43}$

visited on Oct. 1, 2017).

39 The Minutes of the Second Calculation Committee for Procurement Prices on March 15 2012(20) [第2回調達価格等 算定委員会議事録], available at http://www.meti.go.jp/committee/chotatsu_kakaku/002_gijiroku.pdf (last visited on Oct. 1, 2017).

$40 \quad$ Supra note 37.

41 Id.

42 Id.

43 Kenji Asano, Institutional Design and cost estimation for the Feed in Tariff in Japan [我が国の固定価格買取制度 に関する費用負担見通しとその抑制策の検討], CRIEPI Report Y13031 (2014), available at http://criepi.denken. or.jp/jp/kenkikaku/report/detail/Y13031.html (last visited on Oct. 1, 2017). 


\section{E. Purchasing of Existing Renewable Generators and Handling of Capital Investment Subsidy}

Three renewable energy support systems have been implemented in Japan including Renewable Portfolio Standards, ${ }^{44}$ PV FITs, ${ }^{45}$ and FIT. ${ }^{46}$ RPS and PV-FIT, which had been implemented previously, were abolished with the implementation of FIT. The following two points hold true with regard to existing power sources targeted for purchase under both systems.

First, existing facilities targeted as a power source under RPS request the shift to FIT: (a) If having been granted a capital investment subsidy upon installation of power-generation facilities, the purchase price shall be the amount calculated by subtracting the liquidated amount equivalent to said subsidy from the purchase price applicable to new facilities; and (b) The purchase period shall be that calculated by deducting the period of existing operations (the period from the day power generation began until FIT was implemented) from the period applicable to new facilities. ${ }^{47}$

Second, the previous purchase price and period are continually applicable to power sources (PV less than $500 \mathrm{~kW}$ ) targeted by PV-FIT. RPS is discontinued with the implementation of the FIT Law, ${ }^{48}$ but for (existing) facilities approved before the discontinuation of RPS, the rules of RPS "would be effective for a certain period of time." ${ }^{49}$ In this manner, the business environment for these facilities before the implementation of FIT is protected. There are two points at issue in this context. First, if there is a 'specific subsidy' at the time of introducing the power generation facility, existing power sources, that desire a shift to FIT, use the amount derived by subtracting the number equivalent to the confirmed subsidy from the purchase price for new facilities as the purchase price. Second, the purchase period is the period obtained by deducting the existing operation period (period from the beginning of power generation to the FIT Law implementation) from the period applied to the new construction of the facility. ${ }^{50}$

So called RPS was implemented in April 2003. For details, see Box B.

45 So called PV-FIT was implemented in November 2009. For details, see Box C

46 It was implemented in July 2012.

47 FIT Law Supplementary Provision, arts. 11 \& 12.

48 Id. art. 11.

49 Id. art. 12.

50 The process of facility certification on existing generators in the FIT [ 既存発電設備の固定価格買取制度における 設備認定手続きについて], available at $\mathrm{http} / / /$ www.rps.go.jp/RPS/new-contents/pdf/120702exist_plant_fit_nintei_ proc.pdf (last visited on Oct. 1, 2017). 
'Specific subsidy' means the following three capacity investment subsidies: new energy business support subsidy, regional new energy introduction promotion subsidy, and mid- to small-scale hydro and geothermal power development subsidy. ${ }^{51}$ In other words, the number of subsidies at the facilities receive capacity investment subsidy other than 'specific subsidy.' These subsidies are not deducted from the purchase price. The Ministry of Economy, Trade, and Industry stated that: "Subsidies to promote installation of power generation facilities are discontinued with the introduction of FIT and purchase price of the facilities that received these subsidies has the amount equivalent of supply and demand deducted. ${ }^{52}$ Meanwhile, "it is possible to use the subsidy that aims toward policies such as the promotion of forestry." The Ministry of Agriculture, Forestry, and Fisheries explained that the policy objective of facility subsidy that biomass power generation businesses received was to create regional jobs ${ }^{53}$ and its use along with FIT was approved.

As FIT is the purchase price with profit added to all costs, it alone will lead to the same number of jobs. Traditionally, these subsidies supported businesses until they started making a profit up to a certain standard, which was an important tool for achieving the policy objective (employment). Since another system that increases the profit (FIT) has been established and the policy objective has been met, however, the subsidy is no longer necessary. Today, the facility subsidy is a pure profit for businesses and should be thus deducted from the purchase price. In fact, the Government Revitalization Unit (2012) concluded that FIT should be excluded from the budget to avoid the double subsidy situation. ${ }^{54}$ However, after the Abe Administration of Liberal Democratic Party took over the government from December 16, 2012, the Ministry of Agriculture, Forestry, and Fisheries demanded to bring the capital investment subsidy back for the 2012 budget. ${ }^{55}$ In addition, to "protect previous business environment," ultimately, an unreasonable political solution of incorporating existing subsidies in FIT was taken.

$51 \quad I d$.

52 Supra note 37 , at 86.

53 The minutes of the joint research council(the council of Trade and Industry, the Council of Agriculture, Forestry and Fishery, and the council of Environment) in 177th Diet of August 11, 2011 [第177国会経済産業委員会農林水産委 員会環境委員会連合審査会議事録第1号], available at http://www.shugiin.go.jp/internet/itdb_kaigiroku.nsf/html/ kaigiroku/024617720110810001.htm (last visited on Oct. 1, 2017).

54 The Government Revitalization Unit, The evaluation results of the Japanese government's budget screening process on November 26, 2012 [行政刷新会議「新仕分け」の評価結果(2012)], at 39, available at http://warp.da.ndl.go.jp/ info:ndljp/pid/9283589/www.cao.go.jp/sasshin/kaigi/honkaigi/d30/pdf/s1.pdf (last visited on Oct. 1, 2017).

55 The Ministry of Agriculture, Forestry and Fisheries, The main points of requests for replacing budget in FY 2013 [ 平 成25年度農林水産予算入机替え要求の骨子], available at http://www.maff.go.jp/j/budget/pdf/25_irekae.pdf (last visited on Oct. 1, 2017). 
Generally, FIT aims to expand the use of renewable energy. In this regard, the existing companies already started their businesses based on the traditional RPS and have been profiting with the RPS purchase price. In other words, if the purchase price is added to the existing subsidy, it becomes a pure profit for the businesses. The Calculation Committee for Procurement Prices that calculated the purchase price for 2012 did not at all discuss the purchase price of the existing businesses. When gathering public comments to determine governmental and ministerial ordinance of FIT, the purchase prices were incorporated into the public notice ${ }^{56}$ as "the measure for the existing companies" to "promote the replacement of the output enhancement after they complete their business." ${ }^{\text {"57 }}$ Although there was no discussion for the purpose of targeting the existing businesses for FIT, the reason for targeting them for public comments was to promote the replacement of increased output after existing facilities shut down operation.

In the future, it will be necessary to promote disclosure of the actual conditions of pre-existing facilities shifting to FIT and verify the extent of incentives in place to promote the replacement of increased output with the FIT assistance for existing facilities shifting to FIT.

However, this measure has essentially doubled the purchase price of existing power sources, increasing the cost burden. ${ }^{58}$ Among existing facilities, the portion of additional costs for shifting from RPS to FIT has been more than doubled from 2011 (JPY 31.6 billion) to 2012 (JPY 72.9 billion). ${ }^{59}$ Furthermore, the portion of additional costs of both existing facilities shifting to FIT and those not shifting to FIT are added in FIT levy burden (surcharge). Existing facilities not shifting to FIT are estimated at around 3 TWh. As RPS value is JPY 5.2/ kWh, multiplying 3 TWh by JPY 5 yields around JPY 15 billion. Thus, looking at RPS-targeted power sources overall, additional costs in 2012 were just under JPY 90 billion. This means that additional costs would have been approximately tripled by targeting existing facilities for purchase under FIT.

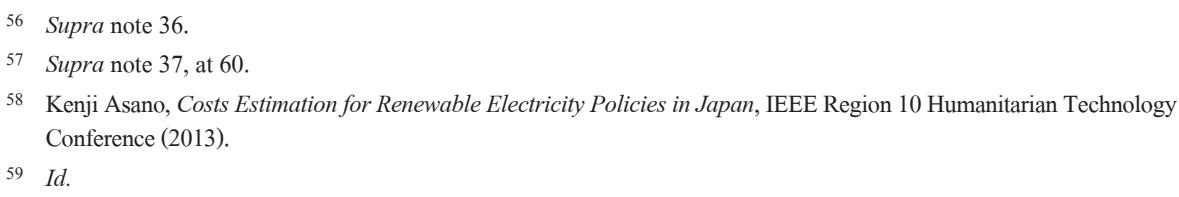


Figure 2: RPS: System Overview and Current Adoption Status ${ }^{60}$

Implemented on April 1, 2003, RPS is a system which requires electricity suppliers to cover a certain percentage of power supply from RE and allows electricity generated from RE to be traded between electricity suppliers as "electricity value" and "the added value of environment improvement through the expansion of RPS value." The characteristics of the RPS system in Japan can be summarized by the following four points (1 through 4), and the post-implementation status of adoption can be described by 5 and 6 .

1. Target for compulsory purchase: This refers to the 10 general electricity suppliers with regional monopolies, such as Tokyo Electric Power Company, as well as specified electricity suppliers and specified-scale electricity suppliers. Owing to an increase in specified-scale electricity suppliers, the number of compulsory suppliers has grown from a total of 25 companies in 2003 to 60 companies in 2011.

2. Targeted power sources: Both new and existing facilities providing PV power, wind, biomass, geothermal binary power generation, and small hydroelectric power.

3. Target output: METI requires electricity suppliers to supply over a certain percentage of RE-derived target output each year based on total electricity sold. This "utilization target" was raised incrementally from 7.32 TWh (about 0.82 percent of total electricity supplied) in 2003 to 12.2 TWh (1.35 percent of total electricity supplied) in 2010. However, as an interim measure for the 7-year period up until 2009 during which this was in effect, the utilization target was adjusted such that suppliers were to achieve the "adjusted base utilization." At 3.28 TWh (0.39 percent of total electricity supplied) in 2003, the latter "adjusted base utilization" was initially about half of the "utilization target" following implementation, but reached the same level as the "utilization target" 7 years later in 2010 .

4. Penalties and flexibility measures: The Minister of Economy, Trade and Industry can advise and direct electricity suppliers if they do not meet requirements (a penalty up to JPY 1 million for violating directives). Suppliers can also apply overage to the required amount in the following fiscal year if they do not use at least the required amount of $\mathrm{RE}$ (banking). Conversely, if they do not meet the required amount, they can carry over a portion of the required amount to the following fiscal year (borrowing).

5. Transaction price: The price of "electricity value + RPS value" is around JPY9-10/kWh (price capped at JPY11). "RPS value" alone is about JPY 5/kWh.

6. Increasing use of wind and biomass: Under RPS, targeted power sources with cheaper generation costs are predominant. As a result, use of the relatively inexpensive wind and biomass energy is increasing, together reaching around 80 percent of target output. 
Figure 3: Photovoltaic Power Feed in Tariff ${ }^{61}$

Implemented since November 1, 2011, PV-FIT was enacted for the purpose of reducing the PV price through technical innovation and creating demand in order to "recapture the global lead" and enact an "emergency economic stimulus package" after being surpassed by Germany in PV installed capacity and productivity. The following three points describe the characteristics of the system after implementation.

1. Targets for compulsory purchase: Only general electricity suppliers are targeted for compulsory purchase, while, under RPS, specified-scale electricity suppliers (PPS: power producers and suppliers) and specified electricity suppliers are excluded.

2. Targeted power sources: PV-FIT was introduced on November 1, 2011 to sell surplus power exceeding self-consumption to generate solar power for residential (less than $10 \mathrm{~kW})$ and non-residential use (10 kW-100 kW).

3. Purchase price and period: A different purchase price was set for each residential and non-residential use. During the purchase period, the 10-year's purchase price for both residential and non-residential use from September 2009 until the end of 2010 was JPY48/kWh, and JPY42/kWh from 2011 until July 2012 when FIT was introduced. This price was set at a level enabling investment to be recovered in around 10-15 years based on capital investment assistance from the national and local governments. It was set to the equivalent of twice the average purchase price (for general households: about JPY24/kWh) for "residential use" on the independent "surplus power purchase menu" of conventional power companies. The price of non-residential use during the same period was increased from JPY24/kWh to JPY40/kWh. First of all, JPY24 was set to "the equivalent of approximately twice the unit-price of retail electricity based on the fact that the purchase price was set at generally JPY11-15/kWh, which is the same as the unit-cost of retail electricity," in order to keep it around "twice the surplus power purchase menu" mentioned above. It was increased to JPY40/kWh since 2011 as compensation for the discontinuation of capital investment assistance for nonresidential use during the same period.

\section{F. Summary}

Challenges with price calculation and financial burden after the implementation of FIT are summarized as follows. First, the transparency in the calculation of purchase price should be improved. In general, the FIT purchase price is determined by a certain amount of political compromise. In Japan, however, the Calculation Committee for Procurement Prices sets the purchase price considering the IRR of each renewable energy business based on the cost data. Therefore, as long as the 
price calculation in FIT advocates objectivity, basic calculations should be clarified. To improve transparency, it is essential to gather and publish the cost data at a higher frequency. Today, the Calculation Committee for Procurement Prices supposedly gathers cost data every six months to a year. But, it is essential to gather and publish such data at a higher frequency to operate FIT. Second, the application period of the purchase price was quietly changed to the beginning of operations during the public comment process. Third, the overlap of FIT and capital investment subsidy was allowed. Fourth, it is challenging to apply FIT purchase price for existing businesses. Calculation of purchase price adds profit to the cost, so that facility subsidy is unnecessary and it creates a double subsidy. FIT originally aims to expand new renewable energy sources. So, when unnecessary increases were made to meet the purchase price for existing businesses, it should have been considered as an unreasonable operation deviating from the original objective.

\section{The amended FIT Law of 2017: Maximizing the Introduction of Renewable Energy While Minimizing National Burden}

\section{A. Decision of Generation Mix in the Long-term Energy Plan of 2015}

Following the introduction FIT in 2012, the installed capacity of renewable energy has been growing rapidly. As of 2015, the renewable electricity ratio in the generated electric power amount of Japan is 14.6 percent. Meanwhile, the levy burden (surcharge) reached JPY 2.1 trillion (aprx. USD 18.7 billion) and to average households amounts up to JPY 792 per month (aprx. USD 7.2) which is equal to 10 percent of their electricity fee. In order to maximize introduction of renewable energy while minimizing national burden, it is required to increase the introduction of renewable energy cost efficiently.

On April 28, 2015, the long-term energy supply and demand outlook subcommittee (outlook subcommittee) published the energy mix proposal (power composition ratio) stating that renewable energy should be 22-24 percent of all electricity sources by $2030 .^{62}$ The biggest challenge was to strike a balance between the introduction

62 The long-term energy supply-demand outlook subcommittee of Advisory Committee for Natural Resources and Energy, The main points of long-term energy supply-demand outlook [長期エネルギ一需給見通し骨子(案)], available at $\mathrm{http} / / / \mathrm{www} . e n e c h o . m e t i . g o . j p /$ committee/council/basic_policy_subcommittee/mitoshi/008/pdf/008_07.pdf (last visited on Oct. 1, 2017). 
of PV and the financial burden; i.e., finding a way to converge the PV investment bubble.

The Agency for Natural Resources and Energy requested the outlook subcommittee to reduce the velectricity cost' - the combination of the fuel cost of thermal and nuclear power and the total purchase price of FIT-by 5 percent from JPY 9.7 trillion to JPY 9.1-9.5 trillion. This request plays a decisive role in easing the PV investment bubble. Total predicted annual purchase price of renewable energy by FIT is JPY 3.7-4 trillion in 2030..$^{63}$ Therefore, the upper limit of the total value that Japan could pay for renewable energy was selected based on the total purchase price bloated by the PV investment bubble.

\section{B. Amendment to the FIT Law}

Based on the decision on the generation mix, the FIT Law was amended and implemented in April 2017. There are three revisions in the amended FIT Law. First, the certification system has been changed. To be certified by the Agency for Natural Resources and Energy, the businesses were required to be ready to implement; in other words, a connection contract with electricity companies was needed. Certification requirements were prepared for facilities that are already certified. Specifically, facilities that have already started their operations can be considered certified by the new system as well. On the other hand, if the certified facility did not have a contract, as long as the connection contract could be drawn by March 31, 2017, the existing certification could be maintained. However, if the contract could not be signed, the certification must be obtained again. In such a case, the FIT price is reduced to that for the new certification.

Second, the system to determine the purchase price has been changed. While PVs of $2 \mathrm{MW}$ or more should be bid for wind power, competition and innovation were promoted by setting a mid- to long-term price target.

Third, there has been a change involving obligated purchasers. Traditionally, FIT electricity was purchased by retail electric utilities. Similar to Germany, however, in the new system, electricity distribution businesses are obliged to collectively purchase FIT electricity sources. In principle, the purchased electricity from FIT generators is passed onto retail businesses through the wholesale electric power market. However,

63 JPY 1.0-1.3 trillion for geothermal, hydro, and biomass, followed by JPY 2.3 trillion for solar, and JPY 0.42 trillion for wind. See The long-term energy supply-demand outlook subcommittee of Advisory Committee for Natural Resources and Energy, the related documents for the main points of long-term energy supply-demand outlook [長期エネル ギー需給見通し骨子(案)関連資料], available at http://www.enecho.meti.go.jp/committee/council/basic_policy_ subcommittee/mitoshi/008/pdf/008_08.pdf (last visited on Oct. 1, 2017). 
if there is an individual contract between retail electric utilities and power generation companies or if there is not a wholesale electric power market in a remote island, the purchased electricity under the FIT Law could be passed onto a specific retail business without going through the market. Currently, the wholesale electric power market is still small and their promotion will be attempted in the future.

\section{Conclusion}

This paper has discussed the enactment and enforcement processes of the FIT Law for Japanese renewables and its amendment of 2017. Since the introduction of FIT in 2012, the installed capacity of renewable energy has been growing rapidly. As of 2015, the renewable electricity ratio in the generated electric power amount of Japan is 14.6 percent, while the levy burden (surcharge) reached JPY 2.1 trillion (aprx. USD 18.7 billion) in 2017.

Under FIT, installation generally expands as the purchase price rises. Therefore, we should consider the burden rather than simply prioritizing installed renewable capacity. Although consideration is given to the maximum limits of consumers' financial burden in the draft bill of FIT, the burden could no longer be controlled because the specific standard in the draft bill was removed in the enactment process of the FIT Law. As a result, the FIT Law now stipulates that the burden of the levy is not excessive to the users of electricity.

However, the upper limit of the burden initially determined by the Japanese Diet was removed through enactment process of the FIT Law. As a result, a fundamental measure could not be taken to control the installation and the burden since the law does not allow for revising the system based on the results of renewable installation, even if the financial burden increases rapidly. Therefore, the Japanese Diet weakened the efficiency of the FIT Law in Japan.

Measures for controlling the cost-burden moving forward include improving the transparency of purchase price calculations and setting a PV purchase price through market mechanism such as auction. Although the Japanese government decided to amend the FIT Law, it is not certain whether the amendment would bring intended outcomes or not.

At a glance, FIT gives the illusion of balancing the environment with the economy. This is because it seems to stimulate current investment in renewable energy, temporarily increase the profits of related companies, and create jobs. However, it 
should be kept in mind that the true nature of the FIT is to extend the purchase period over 15-20 years, which will simply delay the financial burden. An excessively high purchase price must be avoided at all costs.

Consequently, mid-to-long term technical development of new technologies is critical for Japan. However, as no one can precisely predict the future technological advancements, the government policy should diversify investments in overall multiple projects and cut back or abandon them based on repeated evaluations. 